\title{
Pyogenic bacterial infections due to MyD88 deficiency
}

INSERM

\section{Source}

INSERM. (1999). Orphanet: an online rare disease and orphan drug data base. Pyogenic bacterial infections due to MyD88 deficiency. ORPHA:183713

Pyogenic bacterial infection due to MyD88 deficiency is a primary immunodeficiency characterized by increased susceptibility to pyogenic bacterial infections, including invasive pneumococcal, invasive staphylococcal and pseudomonas disease. 